\title{
COVID-19 remote consultation services and population in health inequity-concentrating territories: a scoping review protocol
}

Angélica Baptista Silva ( $\sim$ angelica.baptista@fiocruz.br)

National School of Public Health Sergio Arouca, Oswaldo Cruz Foundation Rio de Janeiro, RJ, Brazil. https://orcid.org/0000-0003-0292-5106

\section{Sérgio Síndico}

Institute of Scientific and Technological Communication and Information in Health, Oswaldo Cruz

Foundation Rio de Janeiro, RJ, Brazil. https://orcid.org/0000-0003-0147-3128

Joyker Peçanha Gomes

National School of Public Health Sergio Arouca, Oswaldo Cruz Foundation Rio de Janeiro, RJ, Brazil. https://orcid.org/0000-0001-8354-8677

\section{Ana Carolina Carneiro}

SAS Brasil https://orcid.org/0000-0003-4308-0568

\section{Arthur Gustavo Fernandes}

SAS Brasil

\section{Sávio Mourão Henrique}

SAS Brasil https://orcid.org/0000-0003-3677-5476

\section{Thaysa Pereira Marinho}

Health Department of Niteroi City, RJ, Brazil https://orcid.org/0000-0002-7207-6085

\section{Valcler Rangel Fernandes}

Oswaldo Cruz Foundation https://orcid.org/0000-0001-7973-4901

\section{Short Report}

Keywords: Outcome and Process Assessment, Health Care, Social Determinants of Health, Telemedicine

Posted Date: February 3rd, 2021

DOI: https://doi.org/10.21203/rs.3.rs-197645/v1

License: (c) (i) This work is licensed under a Creative Commons Attribution 4.0 International License. Read Full License 


\title{
Covid-19 remote consultation services
}

\section{and population in health inequity-}

\section{concentrating territories: a scoping}

\section{review protocol}

\section{Authors}

Angélica Baptista Silva ${ }^{1}$ Sérgio Síndico ${ }^{2}$ Carolina Carneiro ${ }^{3}$ Sávio Mourão Henrique ${ }^{4}$ Arthur Gustavo Fernandes ${ }^{5}$ Joyker Peçanha Gomes ${ }^{6}$ Thaysa Pereira Marinho ${ }^{7}$ Valcler Rangel Fernandes ${ }^{8}$

1. Oswaldo Cruz Foundation

2. Oswaldo Cruz Foundation

3. SAS Brasil

4. SAS Brasil

5. SAS Brasil

6. Oswaldo Cruz Foundation

7. Health Department of Niteroi City, RJ, Brazil

8. Oswaldo Cruz Foundation

\begin{abstract}
Objective: This scoping review aims to map initiatives of measuring the vulnerable populations' satisfaction with teleconsultation and remote consultation services offered by public and private healthcare providers in their respective territories during the COVID-19 pandemic.

Introduction: New teleconsultation-based services were implemented during the pandemic with their monitoring and evaluation processes. It is necessary to know these assessments if services worsen the disparities between vulnerable and economically disadvantaged populations.

Understanding whether the services meet the population's expectations concerning the care to contain the pandemic in their territory can support inclusive policies.
\end{abstract}


Inclusion criteria: This review will include studies on evaluations of teleconsultation-based services offered to the socioeconomically disadvantaged population of a given territory focused on the surveillance, treatment, and prevention of COVID-19. The assessments should describe the process of determining the satisfaction of the population served.

Methods: A comprehensive search will be performed in MEDLINE, EMBASE, Web of Science databases, and other documents in Scopus to identify gray literature. Documents published in English, Portuguese and Spanish will be included from December 2019. The strategy combines descriptors and keywords related to telehealth, Covid-19, patient satisfaction, and vulnerable populations. According to the inclusion criteria, two reviewers will screen titles and abstracts and select the articles for evaluation. The articles selected for full-text screening will be submitted to data extraction, using a tool developed by the third reviewer and approved by the other authors. The data will be presented in semantic networks and narrative summary, aligning with the reviews' objectives and scope.

\section{Introduction}

The ongoing pandemic since 2019 caused by the SARS-CoV-2 virus has led to a policy of social isolation and has stimulated the use of various mechanisms of distance care by health systems (1). National policies on e-health, digital health, telehealth, and telemedicine have been articulated in countries since the 1980s (2). The National States has been exploring its potential intensively ever since. The classic definition of remote consultation or teleconsultation, the basic telemedicine service, is that of an integrated health service delivery system that uses telecommunications and computer technology as a substitute for personal contact between provider and client (3). Studies in the literature address methodologies for assessing and monitoring the application of information and communication technologies to improve health services (4). However, little is known about its influence on the social determinants of health and its contribution to reducing inequities (5), mainly from the point of view of the service's population.

Social determinants are the conditions in the places where people live, learn, work, and play and determine a wide range of risks and outcomes for the health of individuals or a community (6). Some territories in urban centers commonly called periphery carry inequities such as housing without sanitation, poor transport, low income, local violence, and few educational and leisure facilities. It is also worth noting the invisibility of these peripheral communities' voices concerning the satisfaction 
of the health services provided. Observing how the remote consultation services practiced preventing COVID-19, identifying the infected, and supporting the local health system are being evaluated and monitored with the auscultation of the population can contribute to constructing an adequate public policy for these populations. It is a recent knowledge gap deserving to be investigated.

A preliminary search of PROSPERO, MEDLINE, the Cochrane Database of Systematic Reviews and the JBI Evidence Synthesis was conducted. There were no current or underway scoping reviews or systematic reviews on the topic were identified. One study in recruitment was retrieved on Cochrane Database which purpose is to investigate whether an empirically validated treatment for insomnia administered early in the course of sleep disturbance can prevent insomnia disorder or lessen negative mental health outcomes in the wake of the COVID-19 crisis in adults (7), investigation in a group whose clinical vulnerability can reach anyone. Although, this review intends to observe socioeconomic vulnerability as an aggravating factor and a determinant of the health status of peripheral populations, including clinical vulnerabilities such as the condition of having chronic or congenital pathologies (8), and this is especially relevant for health systems in low- and middle-income countries (9). However, pockets of poverty and ghettos of stigmatized populations exist in most cities in the world (10).

Therefore, the purpose of the review is to map initiatives to measure populations' satisfaction in socioeconomic vulnerability situations in peripheral urban areas with remote consultation and teleconsultation devices and services offered by public and private health providers in their respective territories at the time of the COVID -19 pandemic.

\section{Review questions}

What evaluations exist on remote consultation services/teleconsultations focused on surveillance, prevention, and control of COVID-19 and other acute respiratory syndromes with the populations residing in territories concentrators of inequities in urban centers?

Therefore, the research questions that guide this review are:

Is the teleconsultation service aimed at the entire population of a given territory?

Does the teleconsultation service evaluation ask whether the service's citizen/user considers the modality to be safe, effective, and quick to respond? 
Does the teleconsultation service have a counter-referral flow with all levels of the health care network?

Does the teleconsultation service have a cross-referral referral flow with social facilities in the territory in an intersectorial approach?

\section{Keywords}

Outcome and Process Assessment, Health Care; Social Determinants of Health; Telemedicine

\section{Inclusion criteria}

\section{Participants}

This review will consider studies that include teleconsultation / remote consultation services offered to the socioeconomically disadvantaged population of a given territory focused on the surveillance, treatment, and prevention of COVID-19 and other acute respiratory syndromes.

Concept

This review will consider studies that explore the evaluation of teleconsultation services' modalities with their respective developments, such as referrals to other levels of care according to the degree of severity of the diagnosis. The core of this review is to know consolidated experiences of remote consultation in territories that especially shelter people in situations of extreme social vulnerability. Social vulnerability for this investigation is equivalent to a set of inequities (systematic inequality in health between socioeconomically distinct groups and, because it is socially determined, it is unfair and can be avoided) related to the social determinants of health in a given location (11) (12). For the remote consultation or teleconsultation, we adopted the classic definition of an integrated health service delivery system that uses telecommunications and computer technology as a substitute for personal contact between provider and client (13).

Our focus is on the population's perception, especially the economically disadvantaged groups, regarding the outcome of treatment through the type of teleconsultation offered. We intend to identify bottlenecks in this incipient service, and whether it contributes to individuals' health in a locality, slowing down the possibilities of contagion, identifying and forwarding acute cases. 
The discussion as to whether telemedicine (especially teleconsultation) becomes a second-rate medicine alternative due to the in-person absence of the health professional was put on the back burner due to the health emergency represented by the Covid-19 pandemic. However, a remote consultation service is already a digital native, and this can be a facilitator in referring to spaces for social reintegration and assistance to impoverished populations. Therefore, in addition to the favorable outcome for the individual served by the service, the listening, and the perception of that individual regarding the service, we are observing the possible referrals to health units and social equipment that the service can offer.

\section{Data Extraction}

Data will be extracted from articles included in the scoping review by two independent reviewers, using a data extraction tool developed by the other reviewer. The extracted data will include specific details about the studies that develop monitoring and evaluation activities, listening to the user population living in inequality concentrating territories, covered by teleconsultation services for the prevention, treatment, and control of Covid-19. The strategy combines descriptors and keywords related to telehealth, Covid-19, patient satisfaction, and vulnerable populations. These assessments' characteristics for the health system's service's improvement and sustainability will be related to answering the review questions.

A draft extraction tool is described (see Appendix II) and was developed especially for this review, based on the JBI methodology. The draft data extraction tool will be modified and revised as needed during each included article's data extraction process. The full scope review will detail the changes. Any disagreements that arise between the reviewers will be resolved through discussion or with a third reviewer. The authors of the articles can be contacted to request missing or additional data when necessary.

\section{Context}

This review will consider studies that studies that are developed with populations living in impoverished, peripheral communities in urban centers and use satisfaction measurement tools to improve the service according to local needs. It is part of a broader Digital Health Connection project that aims to establish monitoring and evaluation guidelines for teleconsultation in the Brazilian Unified Health System. The empirical observation field is the telemedicine booth installed by a startup company in a highly populated and vulnerable territory in the Rio de Janeiro, Brazil, known as the 
Favela da Maré (14), for remote consultation on COVID-19.

Types of sources

This scoping review will consider both experimental and quasi-experimental study designs, including randomized controlled trials, non-randomized controlled trials, before and after studies, and interrupted time-series studies. Besides, analytical observational studies, including prospective and retrospective cohort studies, case-control studies, and analytical cross-sectional studies, will be considered for inclusion. This review will also consider descriptive observational study designs, including case series, individual case reports, and descriptive cross-sectional studies for inclusion.

Qualitative studies will also focus on qualitative data, including, but not limited to, designs such as phenomenology, grounded theory, ethnography, qualitative description, action research, and feminist research.

In addition, systematic reviews that meet the inclusion criteria will also be considered, depending on the research question.

Text and opinion papers will also be considered for inclusion in this scoping review

\section{Methods}

The proposed scoping review will be conducted in accordance with the JBI methodology for scoping reviews (15).

\section{Search strategy}

The search strategy will aim to locate both published and unpublished primary studies, reviews and text and opinion papers. An initial limited search of MEDLINE (PubMed) and Scopus (Elsevier) was undertaken to identify articles on the topic. The text words in the titles and abstracts of relevant articles, and the index terms used to describe the articles were used to develop a full search strategy for MEDLINE, EMBASE, Scopus and Web of Science (see Appendix I, II, III, and IV). The search strategy, including all identified keywords and index terms, will be adapted for each included information source. The reference lists of articles selected for full text review will be screened for additional papers.

Articles published in English, Portuguese, and Spanish will be included. Articles published after 
December 2019 will be included because the World Health Organization (WHO) received the Chinese authorities' first warning about the Corona Virus on December 31, 2019.

\section{Information sources}

MEDLINE, EMBASE, and Web of Science databases will be screened. Scopus will be the source of unpublished studies and gray literature.

\section{Study/Source of evidence selection}

After the search, all identified records will be grouped and sent to Zotero 5.0.88 (Digital Scholarship, VA, USA), and duplicates removed. There will be a pilot test; two independent reviewers will select the titles and abstracts for evaluation according to the review's inclusion criteria. Potentially relevant documents will be retrieved in full and their citation details imported into the JBI System for Unified Information Management, Evaluation and Review (JBI SUMARI; JBI, Adelaide, Australia). The selected for full-text screening will be evaluated in detail concerning the inclusion criteria by two independent reviewers. The reasons for excluding full-text articles that do not meet the inclusion criteria will be recorded and reported in the scoping review. Any disagreements between the reviewers at each stage of the selection process will be resolved through discussion or with a third reviewer. The research results will be reported in full in the final scoping review, and presented in the Preferred Reporting Items for Systematic Reviews and Meta-analyzes for Scope Reviews (PRISMA-ScR) (16).

\section{Data analysis and presentation}

A preliminary analysis of the articles retrieved using the VOSviewer version 1.6.16 software (Nees Jan van Eck, Ludo Waltman, Universiteit Leiden) presents two main groups of concepts and proves that the extraction of the literature is in line with the expectations of the investigation.

Figure 1. Bibliometric network with two identified clusters, one on care related to telemedicine and the response to the Covid-19 pandemic DOI: 10.6084/m9.figshare.13664096 


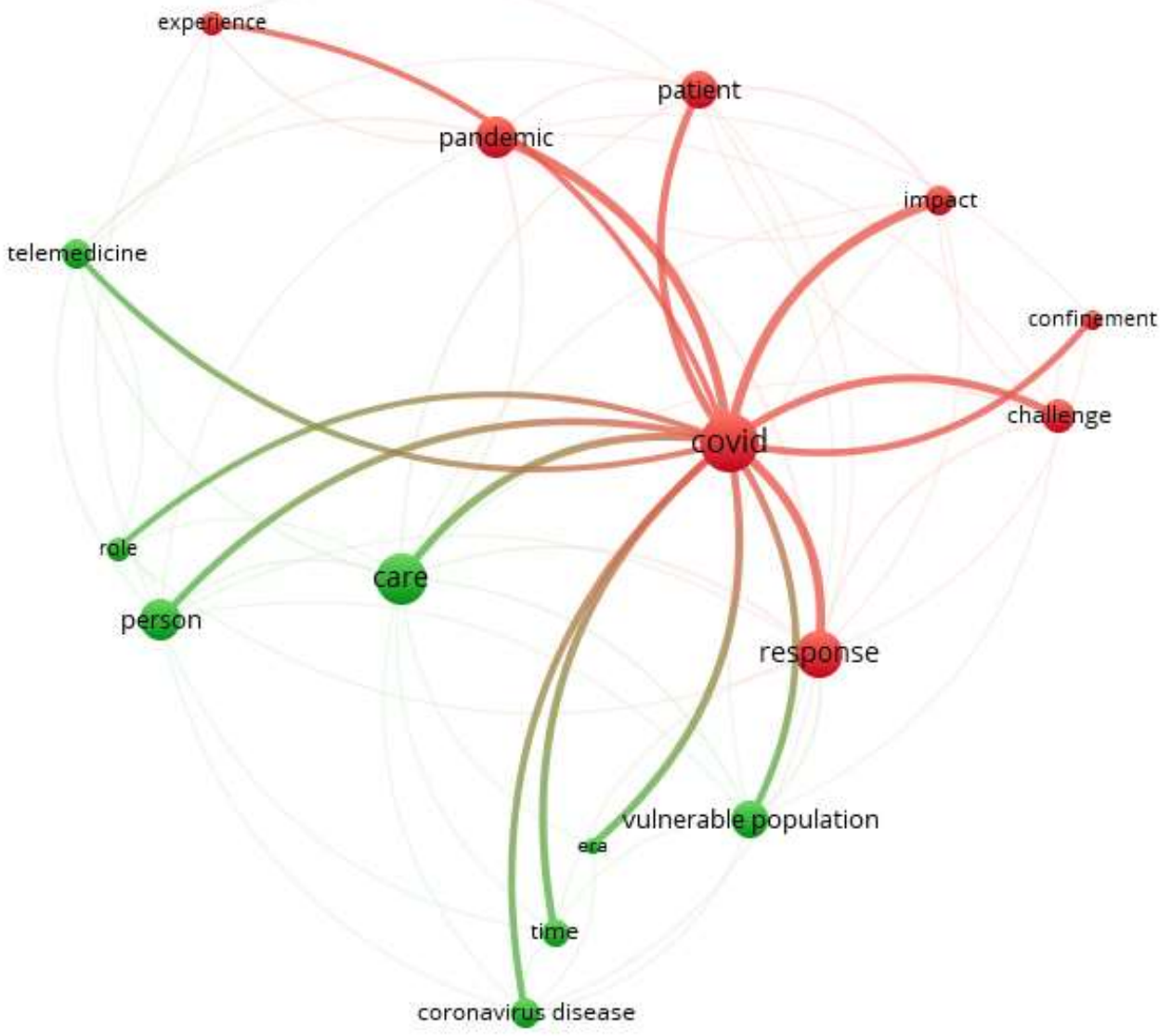

The data will be presented through semantic networks in which the words of the titles and abstracts are counted, their co-occurrence reported and presented in clusters. In this type of visualization, it is possible to know the research paths in the area, the research network's density, and innovations in the research field. A narrative summary from the consensus of the two rounds of reviewers will describe how the mapped results relate to the review's objective and the questions asked.

\section{Funding}

Research financed by the Oswaldo Cruz Foundation (FIOCRUZ-Brazil) within the Digital Health Connection project scope.

\section{Conflicts of interest}

The authors declare no conflict of interest. 


\section{References}

1. Bashshur RL, Doarn CR, Frenk JM, Kvedar JC, Shannon GW, Woolliscroft JO. Beyond the COVID Pandemic, Telemedicine, and Health Care. Telemed J E Health. November 2020;26(11):1310-3.

2. Jennett PA, Affleck Hall L, Hailey D, Ohinmaa A, Anderson C, Thomas R, et al. The socio-economic impact of telehealth: a systematic review. J Telemed Telecare. 2003;9(6):311-20.

3. Bashshur R, Shannon G, Krupinski E, Grigsby J. The Taxonomy of Telemedicine. Telemedicine and E-Health. julho de 2011;17(6):484-94.

4. Clarke M, Thiyagarajan CA. A systematic review of technical evaluation in telemedicine systems.

5. Gamache R, Kharrazi H, Weiner JP. Public and Population Health Informatics: The Bridging of Big Data to Benefit Communities. Yearb Med Inform. August 2018;27(1):199-206.

6. Marmot M, Bell R. Social inequalities in health: a proper concern of epidemiology. Annals of Epidemiology. $1^{\circ}$ de abril de 2016;26(4):238-40.

7. Goldstein-Piekarski, A. et al. Harnessing Telehealth to Mitigate the Impact of the COVID-19 Pandemic on Sleep, Suicidality, and Neuropsychiatric Symptoms. 2002 Jun 1 [last updated 2020 Dec 11; cited 2021 Jan 5]. In: ClinicalTrials.gov [Internet]. Bethesda (MD): U.S. National Library of Medicine. 2021. Available from: Brief Telehealth CBT-I Intervention in the Context of the COVID-19 Pandemic - Full Text View - ClinicalTrials.gov.

8. Formigari R, Marcora S, Luciani GB, Favilli S, Egidy Assenza G, Rinelli G, et al. Resilience and response of the congenital cardiac network in Italy during the COVID-19 pandemic. Journal of Cardiovascular Medicine [Internet]. 2021;22(1). Available from:

https://journals.Iww.com/jcardiovascularmedicine/Fulltext/2021/01000/Resilience_and_response_o f_the_congenital_cardiac.2.aspx

9. OECD. OECD Economic Outlook, Volume 2020 Issue 2 [Internet]. Vol. 2. Paris; 2020. 264 p. Available from: https://www.oecd-ilibrary.org/content/publication/39a88ab1-en

10. Marmot M, Allen J, Goldblatt P, Herd E, Morrison J. Build Back Fairer: The COVID-19 Marmot Review. The Pandemic, Socioeconomic and Health Inequalities in England. [Internet]. London: Institute of Health Equity; 2020 [citado 6 de janeiro de 2021]. Available from:

http://www.instituteofhealthequity.org/resources-reports/build-back-fairer-the-covid-19-marmotreview/build-back-fairer-the-covid-19-marmot-review-full-report.pdf

11. Nesbitt LS. Disparities in COVID-19 Outcomes: Understanding the Root Causes Is Key to Achieving Equity. Journal of Public Health Management and Practice [Internet]. 2021;27. Available from: https://journals.Iww.com/jphmp/Fulltext/2021/01001/Disparities_in_COVID_19_Outcomes_Under standing.10.aspx 
12. Klein R, Huang D. Defining and measuring disparities, inequities, and inequalities in the Healthy People initiative [Internet]. Health People 2010; 2010; USA. Disponível em:

https://www.cdc.gov/nchs/ppt/nchs2010/41_klein.pdf

13. Bashshur RL. Telemedicine nomenclature: What does it mean? Telemedicine Journal.

2000;6(1):1-3.

14. Conheça os vencedores do Prêmio Abril \& Dasa de Inovação Médica 2020 [Internet]. Veja Saúde. [cited 2021 Jan 5]. Available from: https://saude.abril.com.br/medicina/conheca-os-vencedores-dopremio-abril-dasa-de-inovacao-medica-2020/

15. Peters M, Godfrey C, McInerney P, Munn Z, Trico A, Khalil H. Chapter 11: Scoping Reviews. In: Aromataris E, Munn Z, organizers. JBI Manual for Evidence Synthesis [Internet]. JBI; 2020 [cited 2020 Dec 21]. Available from: https://wiki.jbi.global/display/MANUAL/Chapter+11\%3A+Scoping+reviews

16. Tricco AC, Lillie E, Zarin W, O'Brien KK, Colquhoun H, Levac D, et al. PRISMA Extension for Scoping Reviews (PRISMA-ScR): Checklist and Explanation. Ann Intern Med. October, 2nd 2018;169(7):467. 


\section{Appendix I: Search strategy}

The strategy is based on four variables, including terms related to I)Covid-19; 2)Telehealth and Telemedicine; \#)Studies on patient satisfaction or Research on Health Services; including 4)Socioeconomically Vulnerable Populations.

MEDLINE (Pubmed). Search retrieved on December, 2020.

\begin{tabular}{|c|c|c|}
\hline Search & Query & $\begin{array}{l}\text { Records } \\
\text { retrieved }\end{array}$ \\
\hline$\# 1$ & $\begin{array}{l}\text { Coronavirus Infections[mh] OR "Middle East Respiratory Syndrome"[tiab] } \\
\text { OR "Infection Coronavirus"[tiab] "Infections Coronavirus"[tiab] OR } \\
\text { "Coronavirus Infection"[tiab] OR MERS [tiab] "New Coronavirus"[tiab] OR } \\
\text { "Coronavirus Disease"[tiab] OR "Severe Acute Coronavirus 2"[tiab] OR } \\
\text { "2019-ncov"[tiab] OR "ncov } 2019 "[\text { tiab] OR "covid19"[tiab] OR "covid- } \\
19 "[\text { tiab] OR Coronavirus[tiab] OR } \quad \text { "Severe acute respiratory } \\
\text { infections"[tiab] OR Betacoronavirus[tiab] OR "Acute respiratory infections" } \\
\text { [tiab] OR "sars virus"[tiab] OR "Wuhan market virus"[tiab] OR "Wuhan virus } \\
\text { market"[tiab] OR "Wuhan Coronavirus"[tiab] OR "Coronavirus from } \\
\text { Wuhan"[tiab] }\end{array}$ & 93644 \\
\hline$\# 2$ & $\begin{array}{l}\text { Telemedicine[mh] OR "Mobile Health"[tiab] OR "Health Mobile"[tiab] OR } \\
\text { Telehealth[tiab] } \\
\text { OR }\end{array}$ & 345755 \\
\hline$\# 3$ & $\begin{array}{l}\text { Patient Satisfaction[mh] OR "Satisfaction Patient" [tiab] OR Health Services } \\
\text { Research[mh] OR “Health Services Evaluation"[tiab] OR “Evaluation Health } \\
\text { Services"[tiab] OR "Evaluations Health Services"[tiab] OR "Health Services }\end{array}$ & 1863497 \\
\hline
\end{tabular}




\begin{tabular}{|c|c|c|}
\hline & 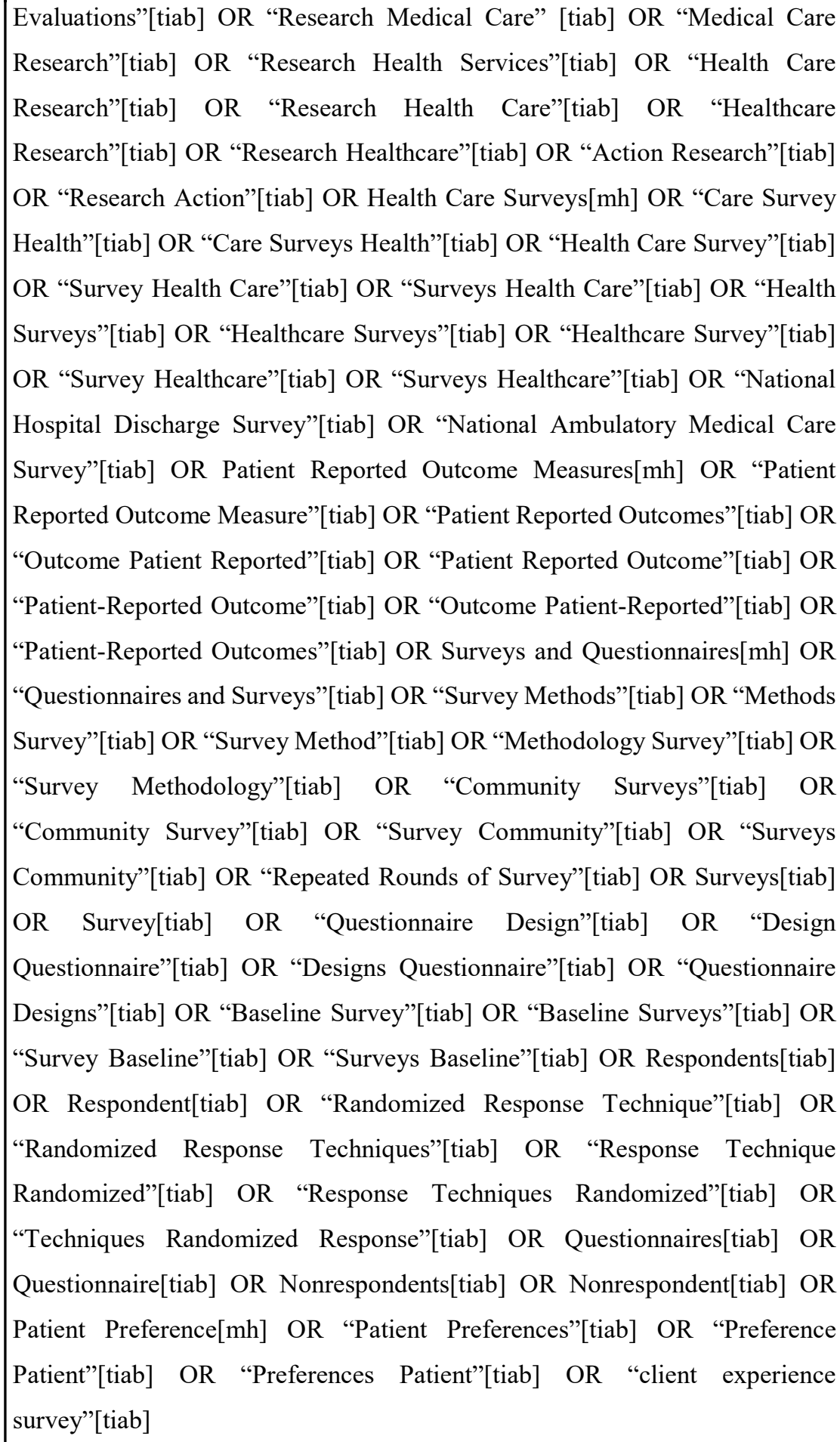 & \\
\hline$\# 4$ & 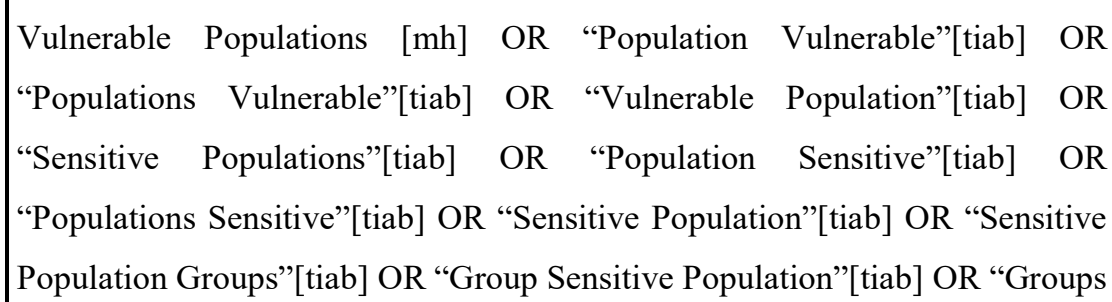 & 65129 \\
\hline
\end{tabular}




\begin{tabular}{|c|c|}
\hline & 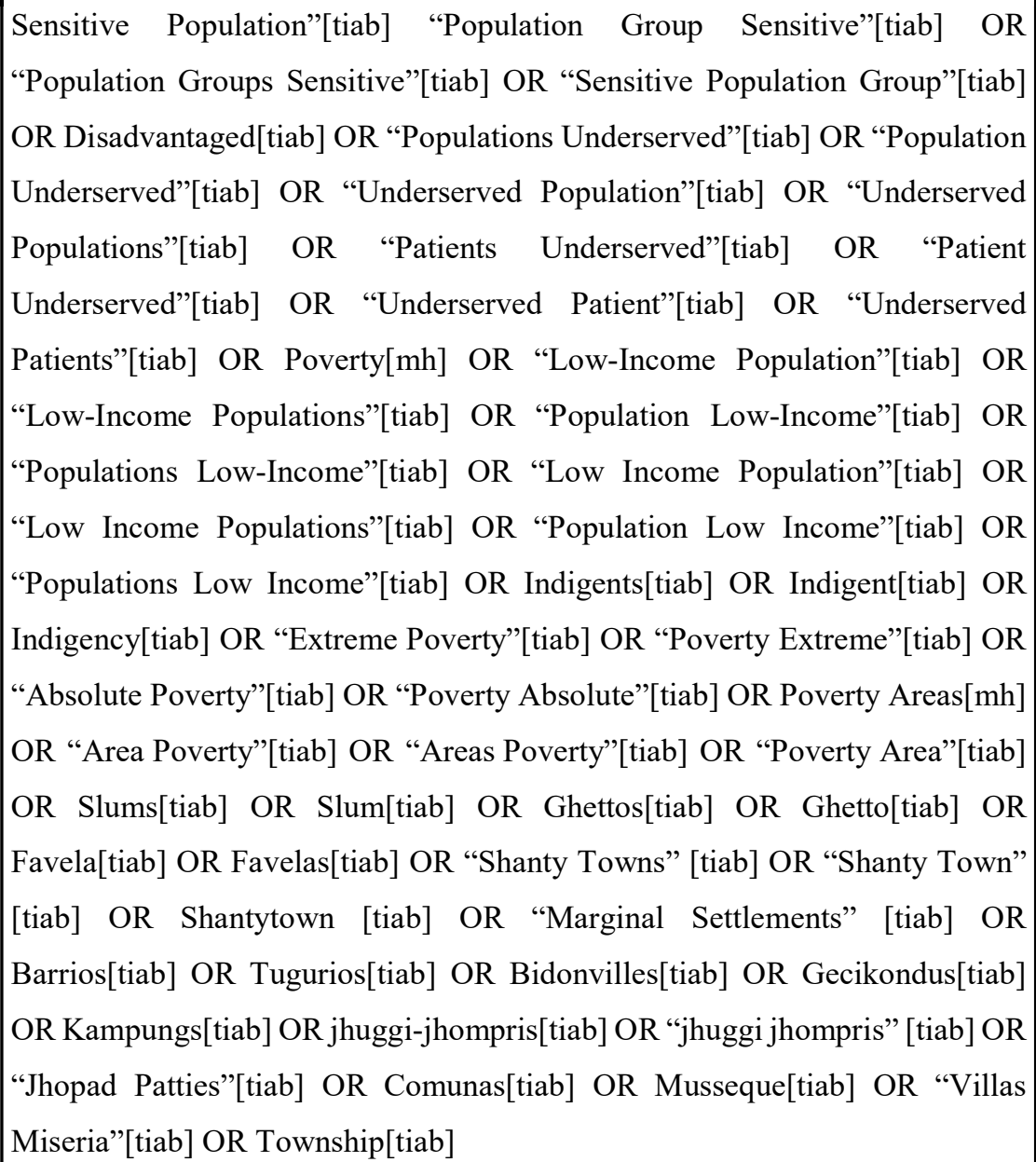 \\
\hline$\# 5$ & $\# 1$ AND \#2 AND \#3 AND \#4 \\
\hline
\end{tabular}

\section{Appendix II: Search strategy}

EMBASE. Search retrieved on December, 2020,

\begin{tabular}{|l|l|c|}
\hline Search & Query & $\begin{array}{c}\text { Records } \\
\text { retrieved }\end{array}$ \\
\hline$\# 1$ & $\begin{array}{l}\text { 'coronavirus infections'/exp OR 'middle east respiratory syndrome':ab,ti OR } \\
\text { 'coronavirus infections':ab,ti OR 'coronavirus infection':ab,ti OR mers:ab,ti OR } \\
\text { 'new coronavirus':ab,ti OR 'coronavirus disease':ab,ti OR 'severe acute } \\
\text { coronavirus 2':ab,ti OR '2019-ncov':ab,ti OR 'ncov 2019':ab,ti OR 'covid19':ab,ti OR } \\
\text { 'covid-19':ab,ti OR coronavirus:ab,ti OR 'severe acute respiratory infections':ab,ti } \\
\text { OR betacoronavirus:ab,ti OR 'acute respiratory infections':ab,ti OR 'sars }\end{array}$ \\
\hline
\end{tabular}




\begin{tabular}{|c|c|c|}
\hline & $\begin{array}{l}\text { virus':ab,ti OR 'wuhan market virus':ab,ti OR 'wuhan virus market':ab,ti OR } \\
\text { 'wuhan coronavirus':ab,ti OR 'coronavirus disease } 2019 \text { ':ab,ti }\end{array}$ & \\
\hline$\# 2$ & 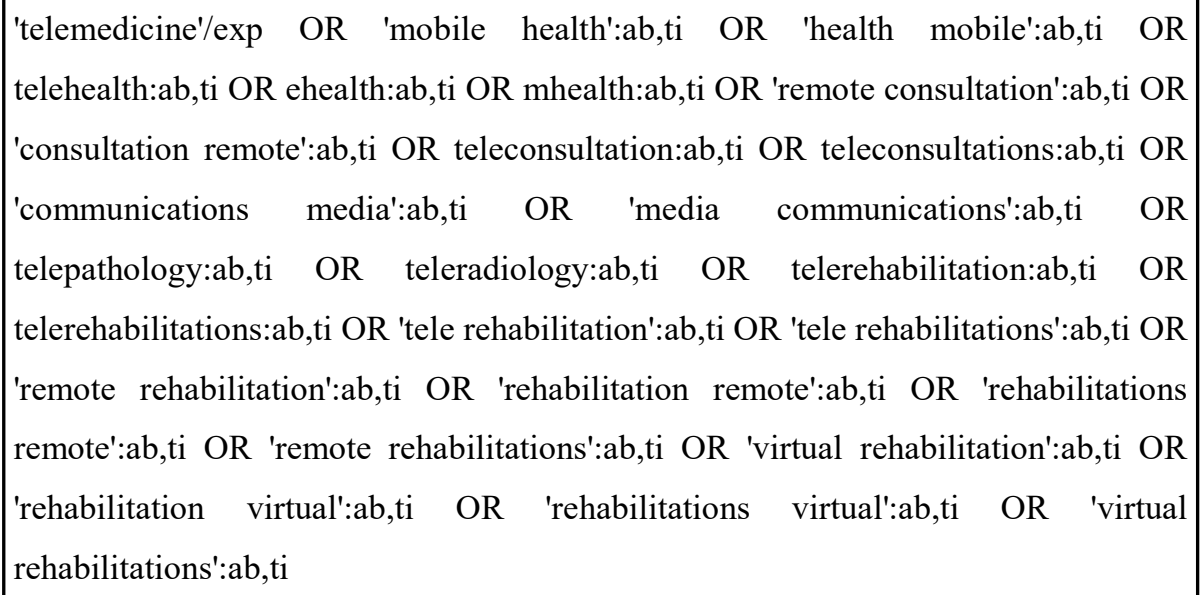 & 58343 \\
\hline \#3 & 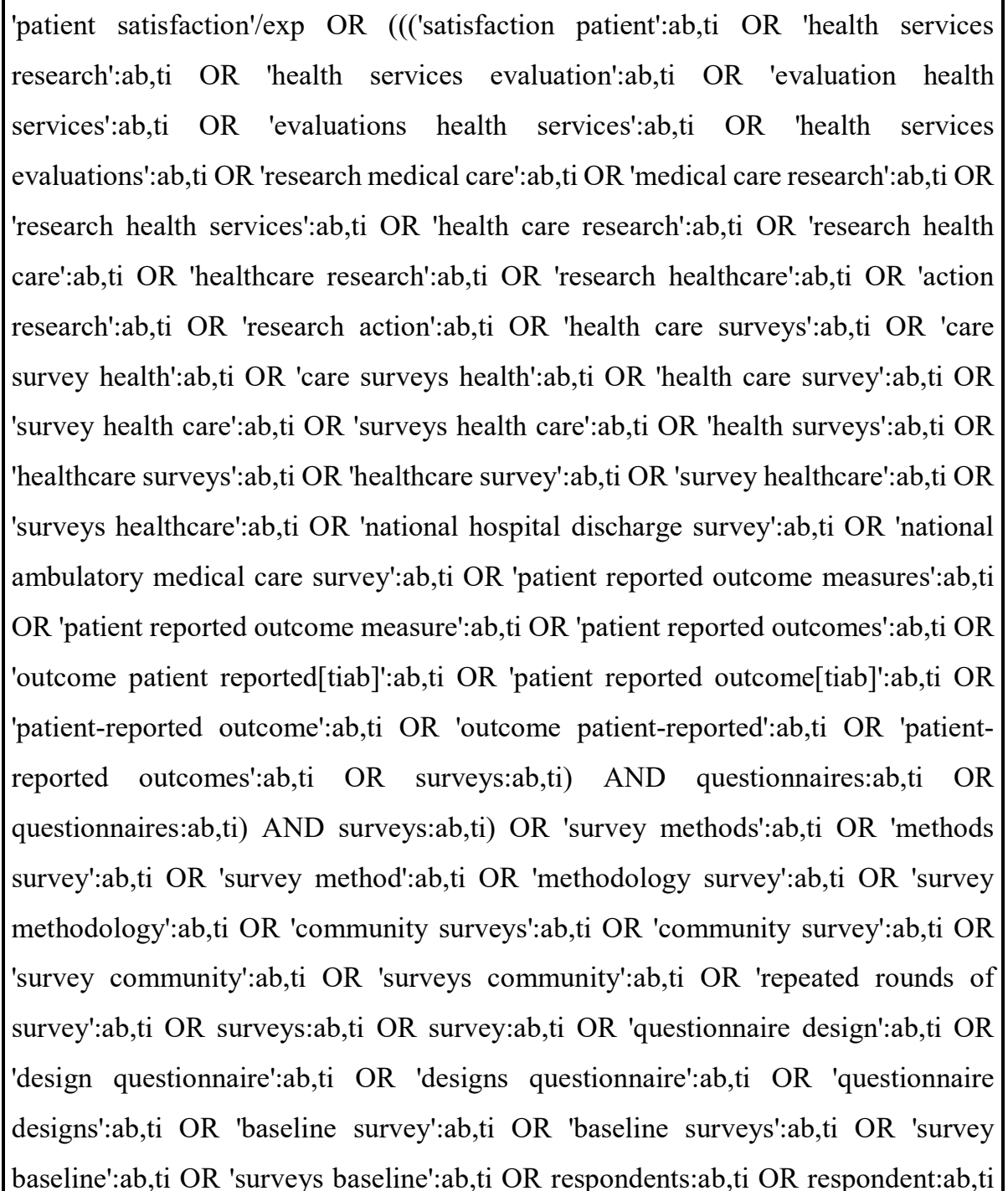 & 1567507 \\
\hline
\end{tabular}




\begin{tabular}{|c|c|c|}
\hline & $\begin{array}{l}\text { OR 'randomized response technique':ab,ti OR 'randomized response techniques':ab,ti } \\
\text { OR 'response technique randomized':ab,ti OR 'response techniques randomized':ab,ti } \\
\text { OR 'techniques randomized response':ab,ti OR questionnaires:ab,ti OR } \\
\text { questionnaire:ab,ti OR nonrespondents:ab,ti OR nonrespondent:ab,ti OR 'patient } \\
\text { preference':ab,ti OR 'patient preferences':ab,ti OR 'preference patient':ab,ti OR } \\
\text { 'preferences patient':ab,ti OR 'client experience survey':ab,ti }\end{array}$ & \\
\hline$\# 4$ & $\begin{array}{l}\text { 'vulnerable populations'/exp } \text { OR 'vulnerable population':ab,ti } \text { OR 'vulnerable } \\
\text { populations':ab,ti OR 'sensitive populations':ab,ti OR 'sensitive population':ab,ti } \\
\text { OR 'sensitive population groups':ab,ti OR 'sensitive group population':ab,ti } \\
\text { OR 'population of sensitive groups':ab,ti OR 'sensitive population group':ab,ti } \\
\text { OR disadvantages:ab,ti } \quad \text { OR 'submerged population':ab,ti } \quad \text { OR 'submerged } \\
\text { populations':ab,ti OR 'low income patient':ab,ti OR 'low income patients':ab,ti } \\
\text { OR 'or poverty':ab,ti OR 'low income population':ab,ti OR 'low income } \\
\text { populations':ab,ti OR 'low-income population':ab,ti OR indigent:ab,ti OR 'extreme } \\
\text { poverty':ab,ti OR 'absolute poverty':ab,ti OR 'poverty absolute':ab,ti OR 'poverty } \\
\text { areas':ab,ti OR 'area poverty':ab,ti OR 'or poverty area':ab,ti OR ghettos:ab,ti } \\
\text { OR ghetto:ab,ti OR favela:ab,ti OR favelas:ab,ti OR slums:ab,ti OR 'marginal } \\
\text { settlements':ab,ti } \quad \text { OR barrios:ab,ti } \quad \text { OR tugurios:ab,ti } \quad \text { OR bidonvilles:ab,ti } \\
\text { OR gecikondus:ab,ti OR kampungs:ab,ti OR 'jhuggi jhompris':ab,ti OR 'jhopad } \\
\text { patties':ab,ti OR communes:ab,ti OR musseque:ab,ti OR 'villas miseria':ab,ti } \\
\text { OR township:ab,ti }\end{array}$ & 96513 \\
\hline \#5 & $\# 1$ AND \#2 AND \#3 AND \#4 & 12 \\
\hline & & \\
\hline
\end{tabular}

\section{Appendix III: Search strategy}

Web of Science. Search retrieved on December, 2020.

\begin{tabular}{|l|l|c|}
\hline Search & Query & $\begin{array}{c}\text { Records } \\
\text { retrieved }\end{array}$ \\
\hline$\# 1$ & $\begin{array}{l}\text { TS=("Coronavirus Infections" OR "Middle East Respiratory Syndrome" OR } \\
\text { "Coronavirus Infection" OR "Coronavirus Infections" OR "Coronavirus Infection" } \\
\text { OR MERS OR "New Coronavirus" OR "Coronavirus Disease "OR" Severe Acute } \\
\text { Coronavirus 2 "OR" 2019-ncov "OR" ncov 2019 "OR" covid19 "OR" covid-19 "OR } \\
\text { Coronavirus OR" Severe acute respiratory infections "OR Betacoronavirus OR" }\end{array}$ & 129802 \\
\hline
\end{tabular}




\begin{tabular}{|c|c|c|}
\hline & $\begin{array}{l}\text { Acute respiratory infections "OR" sars virus "OR" Wuhan Market Virus "OR" Wuhan } \\
\text { Virus Market "OR" Wuhan Coronavirus "OR" Wuhan Coronavirus") }\end{array}$ & \\
\hline \#2 & $\begin{array}{l}\text { TS=(Telemedicine OR "Mobile Health" OR "Health Mobile" OR Telehealth OR } \\
\text { eHealth OR mHealth OR "Remote Consultation" OR "Consultation Remote" OR } \\
\text { Teleconsultation OR Teleconsultations OR "communications media" OR "Media } \\
\text { Communications" OR Telepathology OR Teleradiology OR Telerehabilitation OR } \\
\text { Telerehabilitations OR Tele-rehabilitation OR "Tele rehabilitation" OR Tele- } \\
\text { rehabilitations OR "Remote Rehabilitation" OR "Rehabilitation Remote" OR } \\
\text { "Rehabilitations Remote" OR "Remote Rehabilitations" OR "Virtual Rehabilitation" } \\
\text { OR "Rehabilitation Virtual" OR "Rehabilitations Virtual" OR "Virtual } \\
\text { Rehabilitations") }\end{array}$ & 64586 \\
\hline \#3 & $\begin{array}{l}\text { TS=("Patient Satisfaction" OR "Satisfaction Patient" OR "Health Services Research" } \\
\text { OR "Health Services Evaluation" OR "Evaluation Health Services" OR "Evaluations } \\
\text { Health Services" OR "Health Services Evaluations" OR "Research Medical Care" OR } \\
\text { "Medical Care Research" OR "Research Health Services" OR "Health Care Research" } \\
\text { OR "Research Health Care" OR "Healthcare Research" OR "Research Healthcare" OR } \\
\text { "Action Research" OR "Research Action" OR "Health Care Surveys" OR "Care Survey } \\
\text { Health" OR "Care Surveys Health" OR "Health Care Survey" OR "Survey Health Care" } \\
\text { OR "Surveys Health Care" OR "Health Surveys" OR "Healthcare Surveys" OR } \\
\text { "Healthcare Survey" OR "Survey Healthcare" OR "Surveys Healthcare" OR "National } \\
\text { Hospital Discharge Survey" OR "National Ambulatory Medical Care Survey" OR } \\
\text { "Patient Reported Outcome Measures" OR "Patient Reported Outcome Measure" } \\
\text { OR "Patient Reported Outcomes" OR "Outcome Patient Reported" [tiab] OR "Patient } \\
\text { Reported Outcome" OR "Patient-Reported Outcome" OR "Outcome Patient- } \\
\text { Reported" OR "Patient-Reported Outcomes" OR Surveys and Questionnaires OR } \\
\text { "Questionnaires and Surveys" OR "Survey Methods" OR "Methods Survey" OR } \\
\text { "Survey Method" OR "Methodology Survey" OR "Survey Methodology" OR } \\
\text { "Community Surveys" OR "Community Survey" OR "Survey Community" OR } \\
\text { "Surveys Community" OR "Repeated Rounds of Survey" OR Surveys OR Survey OR } \\
\text { Technique Randomized" OR "Response Techniques Randomized" OR "Techniques }\end{array}$ & 2596715 \\
\hline
\end{tabular}




\begin{tabular}{|c|c|c|}
\hline & $\begin{array}{l}\text { Randomized Response" OR Questionnaires OR Questionnaire OR Nonrespondents } \\
\text { OR Nonrespondent OR "Patient Preference" OR "Patient Preferences" OR } \\
\text { "Preference Patient" OR "Preferences Patient" OR "client experience survey") }\end{array}$ & \\
\hline \#4 & $\begin{array}{l}\text { TS=("Vulnerable populations" OR "Vulnerable population" OR "Vulnerable } \\
\text { populations" OR "Vulnerable populations" OR "Sensitive populations" OR } \\
\text { "Sensitive populations" OR "Sensitive population" OR "Sensitive population groups" } \\
\text { OR "Sensitive Population Group" OR "Sensitive Population Groups" OR "Sensitive } \\
\text { Group Population" OR "Population of Sensitive Groups" OR "Sensitive Population } \\
\text { Group" OR Disadvantages OR "Submerged Populations" OR "Submerged } \\
\text { Population" OR "Submerged Population" OR "Submerged Populations" OR "Low } \\
\text { Income Patients" OR "Low Income Patient" OR "Low Income Patient" OR "Low } \\
\text { Income Patients" OR Poverty OR "Low Income Population" OR "Low Income } \\
\text { Populations" OR "Low-income population" OR "Low-income population" OR "Low- } \\
\text { income population" OR "Low-income population" OR "Low-income population" OR } \\
\text { "Low-income population" OR Indigent OR Indigent OR Indigent OR "Extreme } \\
\text { poverty" OR "Extreme poverty" OR "Absolute poverty" OR "Poverty Absolute" OR } \\
\text { "Poverty areas" OR "Area poverty" OR "Poverty area" OR Slums OR Favelas OR } \\
\text { Ghettos OR Ghetto OR Favela OR Favelas OR Favelas OR Slums OR Slums OR } \\
\text { "Marginal settlements" OR Barrios OR Tugurios OR Bidonvilles OR Gecikondus OR } \\
\text { Kampungs OR jhuggi-jhompris OR "jhuggi jhompris" OR "Jhopad patties" OR } \\
\text { Communes OR Musseque OR "Villas Miseria" OR Township) }\end{array}$ & 394155 \\
\hline \#5 & \#1 AND \#2 AND \#3 AND \#4 & 13 \\
\hline \multicolumn{2}{|c|}{ No limits of date and language } & \\
\hline
\end{tabular}

\section{Appendix IV: Search strategy}

Scopus. Search retrieved on December, 2020.

\begin{tabular}{|l|l|c|}
\hline Search & Query & $\begin{array}{c}\text { Records } \\
\text { retrieved }\end{array}$ \\
\hline$\# 1$ & $\begin{array}{l}\text { TITLE-ABS-KEY ( "Coronavirus Infections" OR "Middle East Respiratory } \\
\text { Syndrome" OR "Coronavirus Infection" OR "Coronavirus Infections" OR }\end{array}$ & 100572 \\
& $\begin{array}{l}\text { "Coronavirus Infection" OR mers OR "New Coronavirus" OR "Coronavirus } \\
\text { Disease" OR "Severe Acute Coronavirus 2" OR "2019-ncov" OR "ncov 2" ) }\end{array}$ & \\
\hline
\end{tabular}




\begin{tabular}{|c|c|c|}
\hline \#2 & 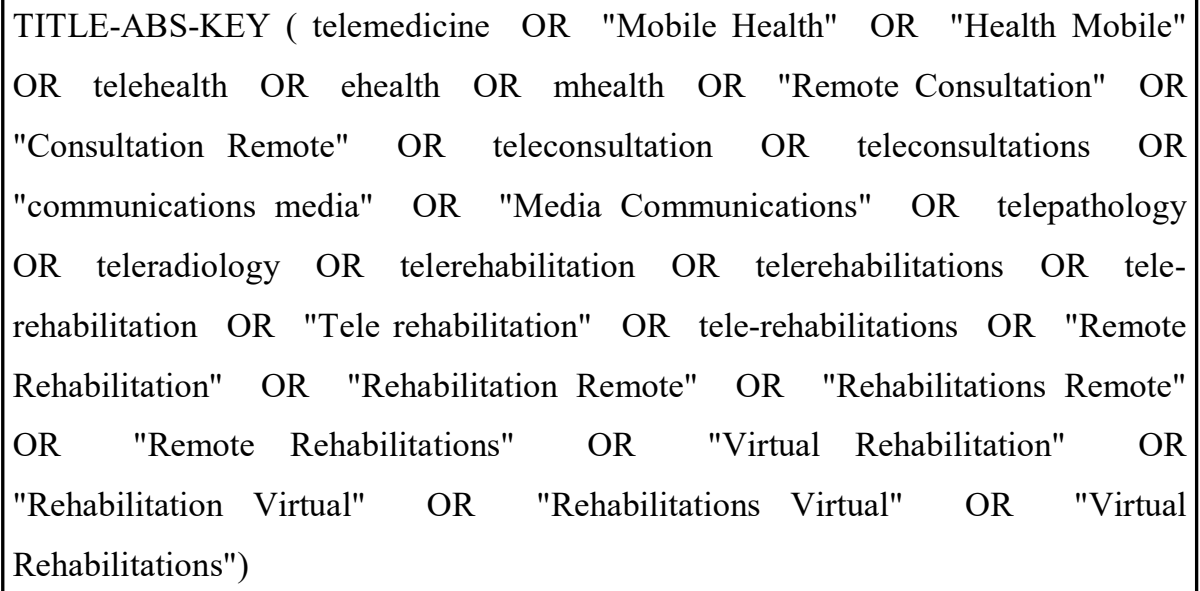 & 93439 \\
\hline$\# 3$ & 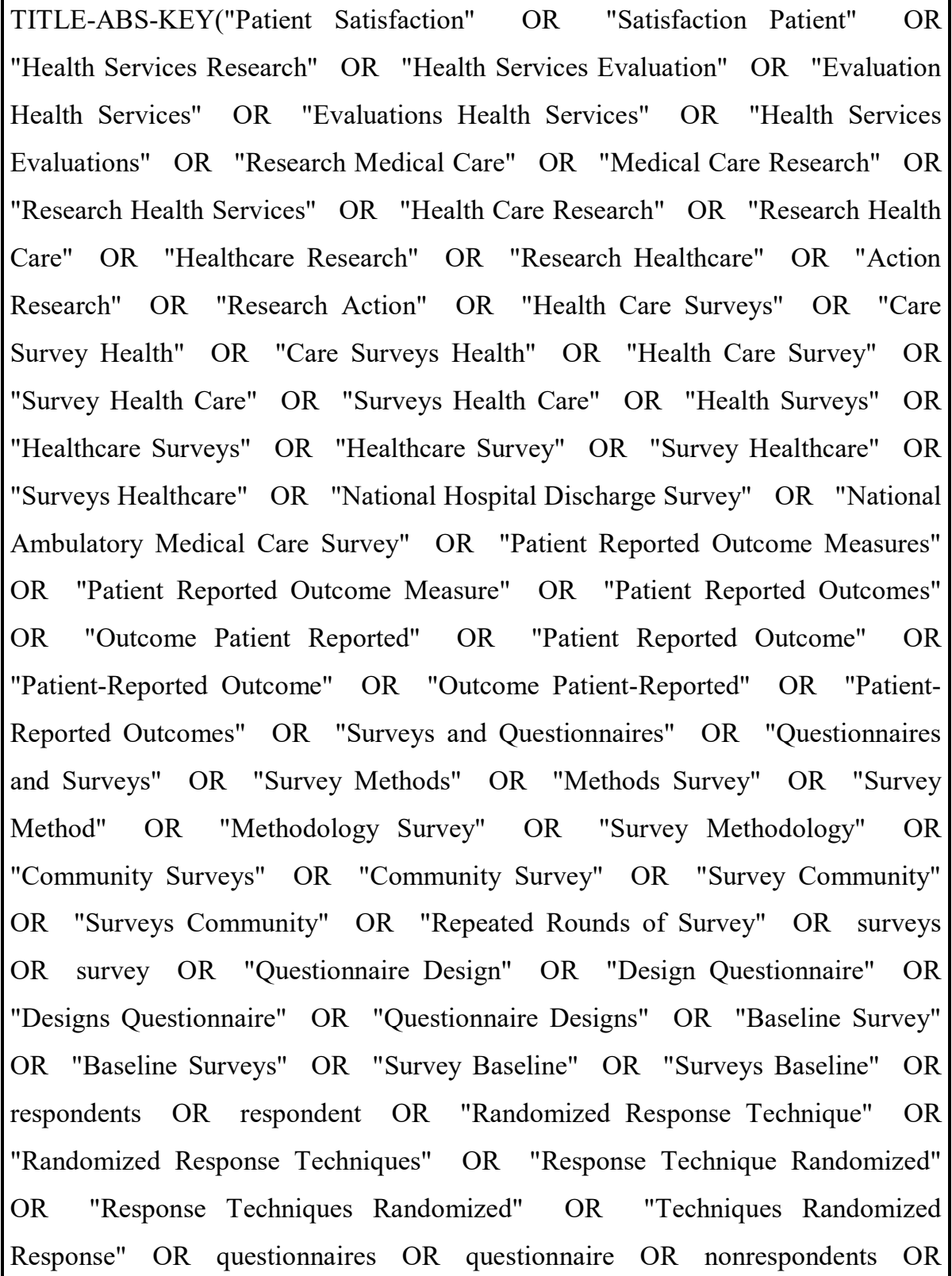 & 3445719 \\
\hline
\end{tabular}




\begin{tabular}{|c|c|c|}
\hline & 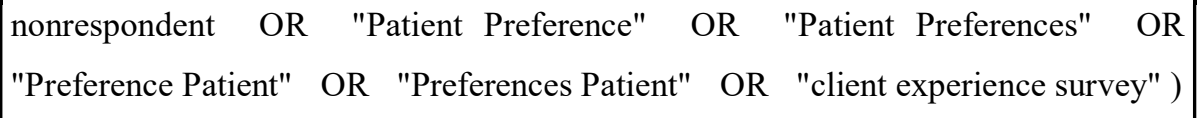 & \\
\hline$\# 4$ & $\begin{array}{l}\text { TITLE-ABS-KEY ( "Vulnerable populations" OR "Vulnerable population" } \\
\text { "Vulnerable populations" OR "Vulnerable populations" } \\
\text { populations" OR "Sensitive populations" }\end{array}$ & 430230 \\
\hline \#5 & \#1 AND \#2 AND \#3 AND \#4 & 27 \\
\hline & & \\
\hline
\end{tabular}

\section{Appendix V: Data extraction instrument}

\begin{tabular}{|l|l|l|l|l|l|l|l|l|}
\hline Authors & Title & Year & Country & $\begin{array}{l}\text { Publication } \\
\text { Type }\end{array}$ & Language & $\begin{array}{l}\text { Objective/ } \\
\text { proposal }\end{array}$ & $\begin{array}{l}\text { Population } \\
\text { studied }\end{array}$ & Methods \\
\hline & & & & & & & & \\
\hline
\end{tabular}




\begin{tabular}{|l|l|l|l|l|l|}
\hline Intervention type & $\begin{array}{l}\text { Duration of } \\
\text { intervention }\end{array}$ & $\begin{array}{l}\text { Does it have a wide } \\
\text { demographic and } \\
\text { territorial scope? }\end{array}$ & $\begin{array}{l}\text { Does the evaluation } \\
\text { ask if it is safe, } \\
\text { effective, and quick } \\
\text { to respond? }\end{array}$ & $\begin{array}{l}\text { Does the service } \\
\text { refer to other Health } \\
\text { Providers? }\end{array}$ & $\begin{array}{l}\text { Does the service } \\
\text { refer to social } \\
\text { equipment? }\end{array}$ \\
\hline & & & & \\
\hline
\end{tabular}


Figures

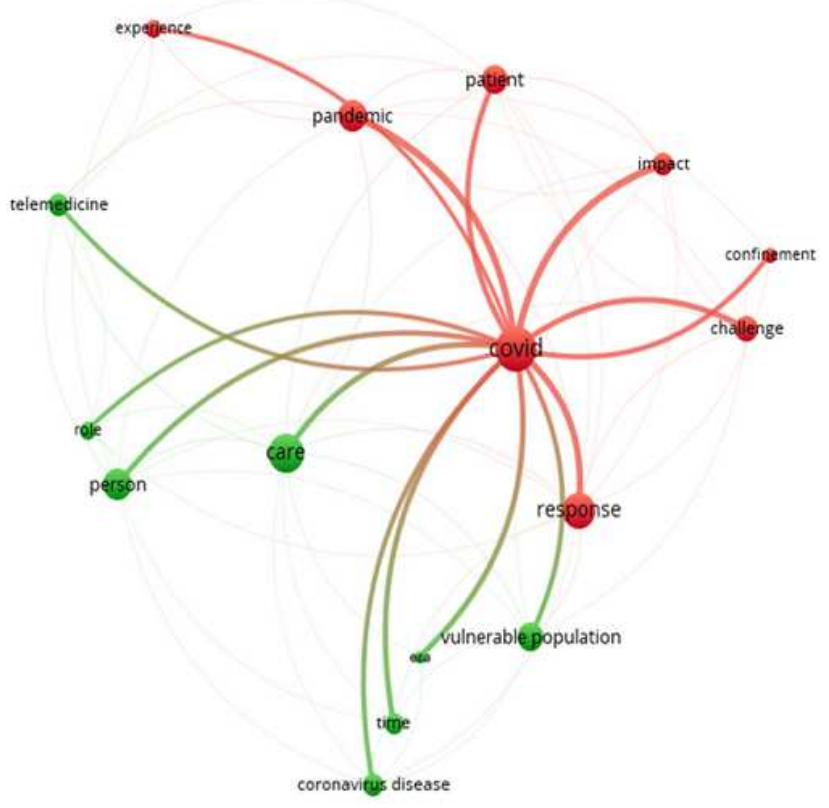

\section{Figure 1}

Bibliometric network with two identified clusters, one on care related to telemedicine and the response to the Covid-19 pandemic DOI: 10.6084/m9.figshare.13664096 